\title{
Dental Casting of Superelastic Ni-Ti Alloy
}

Junzo TAKAHASHI*, Masayuki OKAZAKI*, Hiroshi KIMURA*, and Yasuhiro FURUTA**

*Osaka University Faculty of Dentistry, 1-8, Yamadaoka, Suita, Osaka 565, Japan

**Osaka Dental Institute College, 13-11, Shinmachi 3, Nishi-ku, Osaka 550, Japan

Received on September 4, 1985

Rods of Ni-43.5wt \% Ti alloy were prepared under various casting conditions. Specimens which were melted in a cordierite crucible and cast in a phosphate-bonded investment mold had less strength and elongation than those melted in a copper crucible and cast in a phosphate-bonded investment mold. All castings exhibited superelasticity at room temperature. The upper limit of recoverable strain was about $1.8 \%$. The cast clasps made of the alloy had good fit to a die, good flexibility, and superelasticity.

Key words: Ni-43.5wt \% Ti alloy, Casting condition, Superelasticity

\section{INTRODUCTION}

The development of new biomaterials increases design options and leads to the development of new devices with unique applications. Nickel-titanium alloys differ from conventional alloys in their response to stress. When these alloys (commonly called Nitinol) are plastically deformed at room temperature and heated slightly, they spontaneously revert to their original shape and dimensions, if the original deformation does not exceed about $6 \%$ tensile strain. This feature is called the shape memory effect. It is associated with a reverse transformation of thermoelastic martensite to the parent phase.

The reverse transformation temperature range (RTTR) depends on the titanium content. Nickel-titanium alloys with a RTTR below room temperature exhibit superelasticity, in which relatively large strains, attained on loading beyond the proportional limit, recover completely on unloading at room temperature. This phenomenon is caused by stressinduced martensitic transformation and its subsequent reversion ${ }^{1)}$.

The biocompatibility of the alloys is acceptable ${ }^{2}$ and they have been used as dental archwires in orthodontics ${ }^{3,4}$. However, in partial denture clasp applications, the wire has to be overbent to achieve a desired adaptation. It is difficult to judge its position after elastic spring-back. Furthermore, the clasp is prone to break after several attempts to deform $\mathrm{it}^{5}$.

These problems with wrought Nitinol wire clasps can be solved by using cast nickeltitanium clasps. However, it is difficult to cast nickel-titanium alloy by conventional dental casting techniques because of reaction with oxygen in atmosphere, crucibles and investments ${ }^{5,6)}$. In a previous study ${ }^{7)}$ employing new casting techniques, acceptable castability of a $\mathrm{Ni}-45 \mathrm{wt} \% \mathrm{Ti}$ shape memory alloy was demonstrated.

This study was made to examine the mechanical properties of cast superelastic nickeltitanium alloy and evaluate its characteristics when utilized in the form of cast clasps. 


\section{MATERIALS AND METHODS}

$\mathrm{Ni}-43.5 \mathrm{wt} \% \mathrm{Ti}(\mathrm{Ni}-48.5 \mathrm{at} \% \mathrm{Ti})$ alloy was prepared by melting high purity nickel $(99.97$ $\%)^{*}$ and titanium $(99.7 \%)^{* *}$ in a dental arc-melting furnace ${ }^{+}$with a copper crucible ${ }^{+}$in an inert atmosphere of argon. A dental $\mathrm{Co}-\mathrm{Cr}$ alloy ${ }^{\dagger}$ was used for comparison with the NiTi alloy.

Wax patterns in the form of rods $1.5 \mathrm{~mm}$ in diameter and $50 \mathrm{~mm}$ in length were used for casting of test specimens, and were invested with a magnesia cement investment $(\mathrm{MgO}=$ $96 \%)^{\dagger \dagger}$ or a phosphate-bonded investment ${ }^{\#}$. The invested pattern was slowly burned out from ambient temperature to $800^{\circ} \mathrm{C}$ and then heat-soaked for $1 \mathrm{hr}$ at this temperature prior to casting.

The Ni-Ti alloy was cast by means of a dental argon-arc pressure casting machine ${ }^{+}$with a copper crucible ${ }^{+}$or a dental induction pressure casting machine ${ }^{\#}$ with a cordierite (2 $\mathrm{MgO} \cdot 2 \mathrm{Al}_{2} \mathrm{O}_{3} \cdot 5 \mathrm{SiO}_{2}$ ) crucible ${ }^{\sharp}$. The $\mathrm{Co}-\mathrm{Cr}$ alloy was cast into the phosphate-bonded investment molds by the former machine. The resulting castings were removed from molds by sand blasting. Castings of $1.5 \phi \times 50 \mathrm{~mm}$ rod were used as specimens for shape memory tests and mechanical property tests.

The reverse transformation temperature range (RTTR) was determined by shape memory tests, which were carried out by immersing the straight rod into liquid nitrogen, bending it by an angle of $30^{\circ}$, pulling out it from liquid nitrogen and measuring the change in angle with an increase in temperature. The purpose of cooling to liquid nitrogen temperature was to change the microstructure of alloy to the martensite state.

Superelasticity of the cast $\mathrm{Ni}-\mathrm{Ti}$ alloy was examined by repeating loading cycles in bending and tensile tests. These tests were carried out on a universal testing machine ${ }^{++}$ at room temperature, with a crosshead speed of $1.0 \mathrm{~mm}$ per min and a span of $20 \mathrm{~mm}$ (for bending tests) or a gauge length of $30 \mathrm{~mm}$ (for tensile tests). Mechanical properties of both cast alloys were also measured by the same methods. Five specimens from each casting condition group were tested. From the resulting recordings, maximum bending force, deflection, ultimate tensile strength and percent elongation were calculated for each group. The results were compared using an analysis of variance.

\section{RESULTS}

Fig. 1 shows the shape recovery behavior of $\mathrm{Ni}-43.5 \mathrm{wt} \% \mathrm{Ti}$ alloy castings. The horizontal bars represent the standard deviation range of shape recovery temperature at each angle. The specimen reverted to the original shape after an increase in temperature to $-10^{\circ} \mathrm{C}$. The temperature of perfect recovery was $-26.5 \pm 3.4^{\circ} \mathrm{C}$ (mean \pm standard devia-

* Mitsubishi Metal Co., Tokyo, Japan

** Kobe Steel Co., Kobe, Japan

+ Castmatic, Iwatani \& Co., Osaka, Japan

++ Instron Co., Canton, Mass., U.S.A.

† Tailium Hard, Taisei Dental Mfg. Co., Katano, Osaka, Japan

i† M-4 Magnesia Cement, Nippon Kagaku Togyo Co., Tokyo, Japan

* Tai-vest, Taisei Dental Mfg. Co., Katano, Osaka, Japan

* Argoncaster DX, Shofu Dental Mfg. Co., Kyoto, Japan 


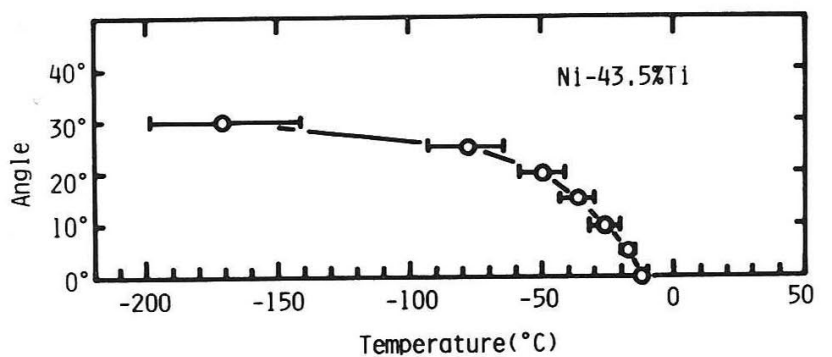

Figure 1 Shape recovery process of $\mathrm{Ni}-43.5 \mathrm{wt} \% \mathrm{Ti}$ alloy castings bent by an angle of $30^{\circ}$ at liquid nitrogen temperature. The value indicates the mean \pm standard deviation, determined by results of four specimens which were melted in a cordierite crucible and cast in magnesia cement molds.
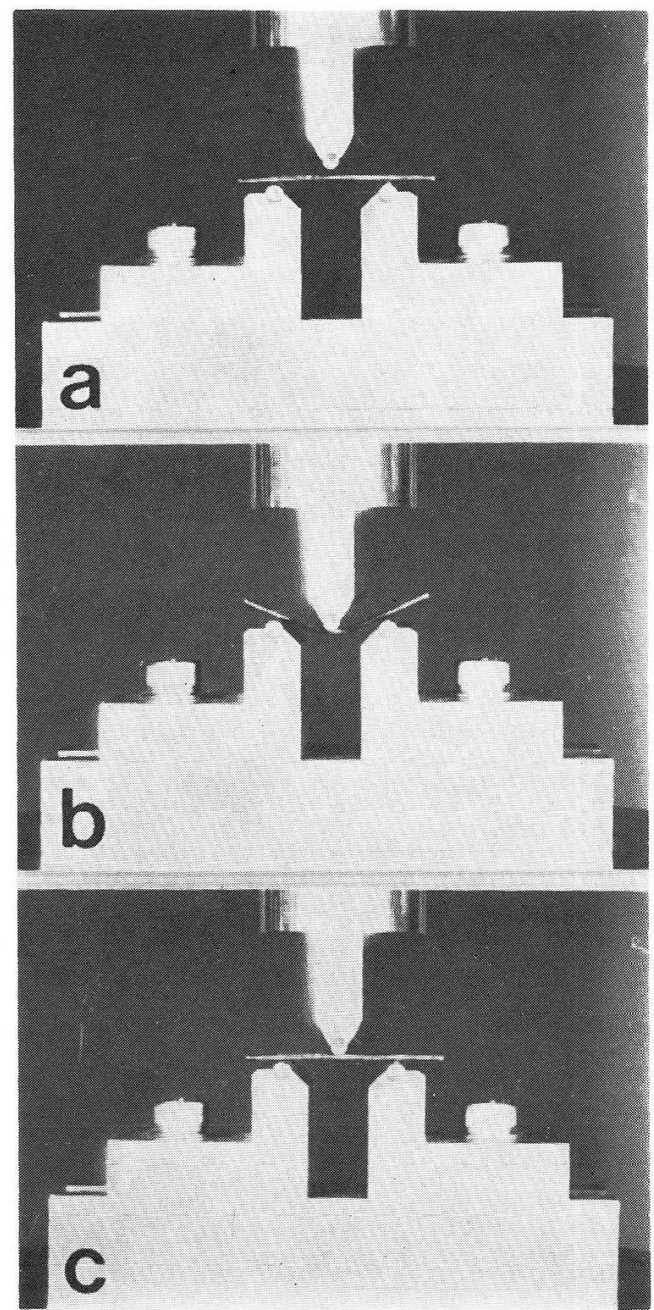

Figure 2 Bending behavior of $\mathrm{Ni}-43.5 \mathrm{wt} \% \mathrm{Ti}$ alloy castings at room temperature; a) an original state, b) a bent state during load, and c) a recovered state after unload. 


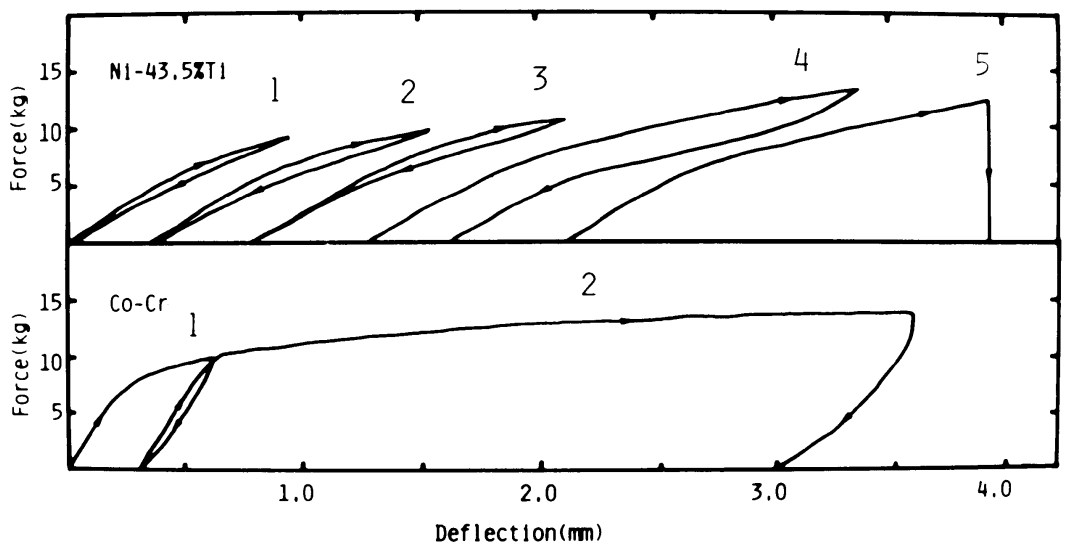

Figure 3 Representative force-deflection curves in bending test of both $\mathrm{Ni}-43.5 \mathrm{wt} \% \mathrm{Ti}$ alloy and $\mathrm{Co}-\mathrm{Cr}$ alloy castings prepared in a copper crucible with phosphatebonded investment molds.

tion) in the case of a ccpper crucible and $-12.1 \pm 3.3^{\circ} \mathrm{C}$ in the case of a cordierite crucible.

Three stages of bending a cast $\mathrm{Ni}-43.5 \mathrm{wt} \% \mathrm{Ti}$ rod at room temperature are shown in Fig. 2; (a) the undeformed stage, (b) the deformation stage and (c) the shape recovery stage. Fig. 3 compares the bending test data of the cast Ni-Ti alloy with the cast $\mathrm{Co}-\mathrm{Cr}$ alloy. Loading cycles (indicated by number on this figure) were repeated in one specimen of each alloy. After loading beyond the proportional limit, the $\mathrm{Ni}-\mathrm{Ti}$ alloy recovers on unloading and the $\mathrm{Co}-\mathrm{Cr}$ alloy has a large permanent deflection. Fig. 4 compares similarly the tensile test data of both cast alloys.

Table 1 shows the effect of casting conditions on mechanical properties of Ni-43.5 $\mathrm{wt} \% \mathrm{Ti}$ alloy. The values indicate the mean and standard deviation. When tested using

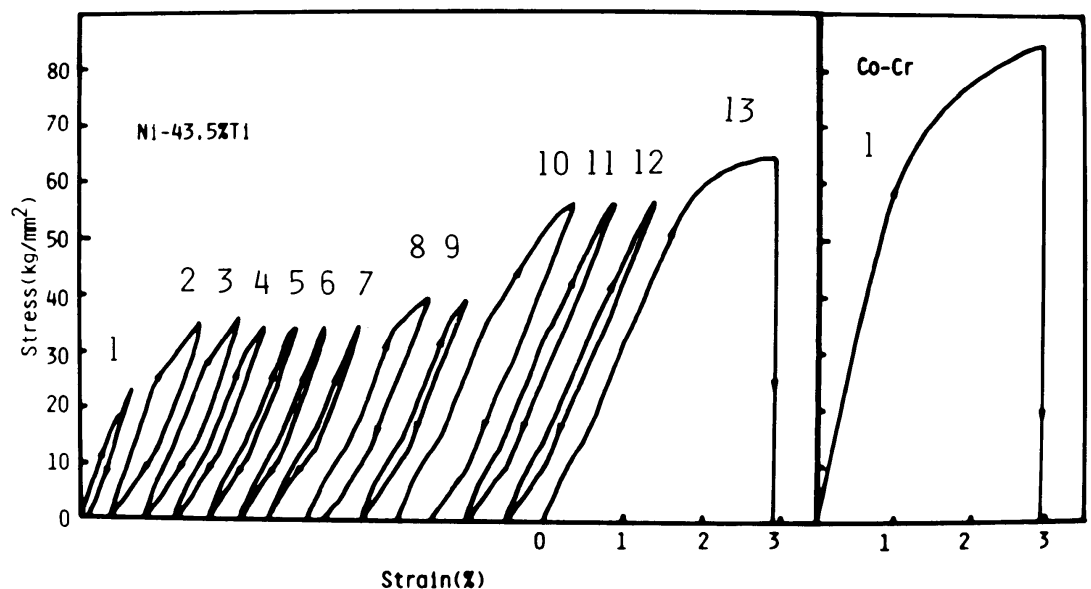

Figure 4 Representative stress-strain curves in tensile test of both $\mathrm{Ni}-43.5 \mathrm{wt} \% \mathrm{Ti}$ alloy and $\mathrm{Co}-\mathrm{Cr}$ alloy castings prepared in a copper crucible with phosphate-bonded investment molds. 
Table 1 Mechanical properties of Ni-43.5\% Ti alloy castings $(1.5 \mathrm{~mm} \phi)$

\begin{tabular}{lllllll} 
& Investments & Crucibles & $\begin{array}{c}\text { Maximum } \\
\text { bending } \\
\text { force } \\
(\mathrm{kg})\end{array}$ & $\begin{array}{c}\text { Deflection } \\
(\mathrm{mm})\end{array}$ & $\begin{array}{c}\text { Ultimate } \\
\text { tensile } \\
\text { strength } \\
\left(\mathrm{kg} / \mathrm{mm}^{2}\right)\end{array}$ & $\begin{array}{c}\text { Elongation } \\
(\%)\end{array}$ \\
\cline { 1 - 4 } A & Magnesia cement & Copper & $11.8 \pm 2.6$ & $2.01 \pm 0.76$ & $59.9 \pm 6.0$ & $2.2 \pm 0.3$ \\
B & Magnesia cenent & Cordierite & $12.9 \pm 0.2$ & $1.91 \pm 0.12$ & $67.2 \pm 7.7$ & $2.9 \pm 1.0$ \\
C & Phosphate-bonded & Copper & $12.0 \pm 1.2$ & $2.24 \pm 0.71$ & $63.9 \pm 8.5$ & $2.8 \pm 0.9$ \\
D & Phosphate-bonded & Cordierite & $9.3 \pm 1.7$ & $1.03 \pm 0.20$ & $43.9 \pm 1.6$ & $1.5 \pm 0.1$
\end{tabular}

The value indicates as the mean \pm standard deviation, determined by the results of five specimens in each group.

Table 2 Comparison of tensile properties between $\mathrm{Ni}-43.5 \% \mathrm{Ti}$ and $\mathrm{Co}-\mathrm{Cr}$ alloys castings $(1.5 \mathrm{~mm} \phi)$

\begin{tabular}{lcc}
\hline Alloys & $\begin{array}{c}\text { Ultimate tensile } \\
\text { strength } \\
\left(\mathrm{kg} / \mathrm{mm}^{2}\right)\end{array}$ & $\begin{array}{c}\text { Elongation } \\
(\%)\end{array}$ \\
\hline $\mathrm{Ni}-43.5 \% \mathrm{Ti}$ & $63.9 \pm 8.5$ & $2.8 \pm 0.9$ \\
$\mathrm{Co}-\mathrm{Cr}$ & $79.0 \pm 6.2$ & $3.1 \pm 0.5$ \\
\hline
\end{tabular}

(Copper crucible-phosphate-bonded investment)

an analysis of variance, a significant difference was found in the maximum bending force and deflection $(\mathrm{p} \leq 0.05)$. The multiple pairwise comparisons of the four casting conditions using t-test showed the force and the deflection of the $\mathrm{D}$ condition to be significantly lower than those of all other casting conditions.

A comparison of the ultimate tensile strength by an analysis of variance showed a significant difference $(\mathrm{p} \leq 0.01)$. Pairwise comparisons showed the strength of the D condition to have a significantly lower value than that of all other casting conditions. At the elongation value, an analysis of variance for the casting conditions showed a significant difference $(\mathrm{p} \leq 0.05)$. Pairwise comparisons showed the value of $\mathrm{D}$ condition to be significantly lower than those of $\mathrm{B}$ and $\mathrm{C}$ conditions.

Table 2 shows the tensile properties of $\mathrm{Ni}-\mathrm{Ti}$ and $\mathrm{Co}-\mathrm{Cr}$ alloys which were melted in a copper crucible and cast in phosphate-bonded investment molds. A t-test analysis of the ultimate tensile strength for both cast alloys showed the strength of the Ni-Ti alloy to be significantly lower than that of the Co-Cr alloy $(\mathrm{p} \leq 0.05)$. A comparison of elongation value of these alloys by $t$-test showed no significant difference $(p \leq 0.05)$.

Fig. 5 demonstrates that the cast clasps of $\mathrm{Ni}-43.5 \mathrm{wt} \% \mathrm{Ti}$ alloy do provide good fit to a die if cast into a phosphate-bonded investment mold.

\section{DISCUSSION}

In general, the temperature of perfect recovery after deformation corresponds to the RTTR. This indicates that the Ni-43.5wt $\%$ Ti alloy castings can exhibit superelasticity at temperatures above about $-10^{\circ} \mathrm{C}$ (see Fig. 1). After the castings are deformed beyond the proportional limit, the Ni-Ti alloy has a very small permanent set (see Fig. 3 and Fig. 4). 

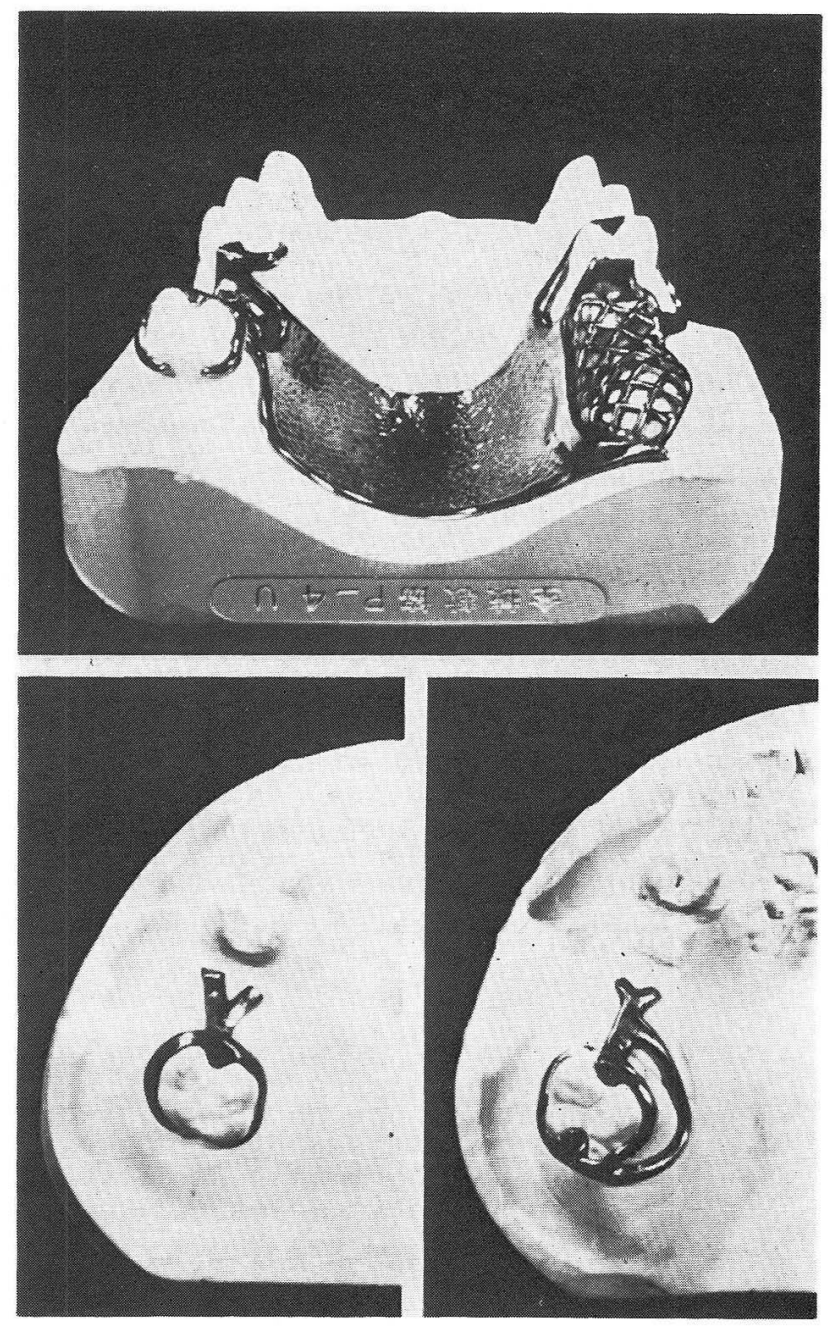

Figure 5 Cast clasps and a partial denture of $\mathrm{Ni}-43.5 \mathrm{wt} \% \mathrm{Ti}$ alloy on stone dies.

This fact indicates that the cast $\mathrm{Ni}-43.5 \mathrm{wt} \% \mathrm{Ti}$ alloy has similar superelasticity to orthodontic wrought Nitinol wire.

The upper limit for recoverable strain for $\mathrm{Ni}-43.7 \mathrm{wt} \% \mathrm{Ti}$ alloy is $7 \%$ (including elastic strain) in the as-quenched condition, and decreases to $5 \%$ after being aged at $500^{\circ} \mathrm{C}$ for $1 \mathrm{hr}^{8)}$. In our study, the upper limit of recoverable strain is about $1.8 \%$ as shown in Fig. 4. The small value may be due to the slow cooling of the castings without solutionheat-treatment, and the alloy reacted slightly with oxygen during melting and casting.

Titanium in contact with silica becomes oxidized at high temperatures due to a strong affinity for oxygen, even in vacuum. Therefore, silica is not adequate for refractories for the melting and casting of titanium and its alloys. Table 1 shows that castings prepared in a cordierite crucible with phosphate-bonded investment molds have less strength and 
elongation. This means that a molten $\mathrm{Ni}-\mathrm{Ti}$ alloy reacted slightly with silica in both a cordierite crucible and phosphate-bonded investment molds. Magnesia cement is suitable for molds of titanium alloys on the basis of the standard free energy of formation of oxide. On the other hand, in dental casting the casting shrinkage has to be compensated by the expansion of investments. However, the expansion of magnesia cement is too low for dental casting of titanium and its alloys ${ }^{6,7)}$.

Table 1 shows that castings prepared with magnesia cement molds and with phosphatebonded investment molds in a copper crucible have nearly equal strength and elongation. Furthermore, Table 2 shows that Ni-Ti alloy castings have nearly equal elongation values compared to $\mathrm{Co}-\mathrm{Cr}$ alloy castings, prepared in a copper crucible with phosphate-bonded investment molds. Therefore, the Ni-Ti alloy should be useful for cast clasps as shown in Fig. 5. These cast clasps had good fit, good flexibility related to the low modulus of elasticity and the superelasticity of the Ni-Ti alloy. The flexibility is believed to reduce transmission of excessive force to the abutment tooth ${ }^{9)}$. The superelasticity permits the use of cast clasps in deeper undercuts.

\section{CONCLUSIONS}

$\mathrm{Ni}-43.5 \mathrm{wt} \% \mathrm{Ti}$ alloy castings showed superelasticity at room temperature and nearly equal elongation to $\mathrm{Co}-\mathrm{Cr}$ alloy castings, prepared in a copper crucible with phosphatebonded investment molds. The cast $\mathrm{Ni}-43.5 \mathrm{wt} \% \mathrm{Ti}$ clasps displayed superelasticity, good flexibility and good fit to a die.

\section{REFERENCES}

1) Otsuka, K., Wayman, C.M.: Pseudoelasticity and stress-induced martensitic transformation, Review on the deformation behavior of materials, ed. Feltham, P., Freund, 1977.

2) Castleman, L.S., Motzkin, S.M., Alicandri, F.P., Banawit, V.L. and Johnson, A.A.: Biocompatibility of Nitinol alloy as an implant material, $J$ Biomed Mater Res 10: 695-731, 1976.

3) Perkins, J.: Shape memory effects in alloys, Plenum, 1975.

4) Andreasen, G.F. and Morrow, R.E.: Laboratory and clinical analyses of Nitinol wire, Am J Orthod 73: 142-151, 1978.

5) Civjan, S., Huget, E.F. and DeSimon, L.B.: Potential application of certain nickel-titanium (Nitinol) alloys, J Dent Res 54: 89-96, 1975.

6) Ida, K., Takeuchi, M., Togaya, T., Tsutsumi, S., Ikeda, K. and Maruyama, K.: Studies on the dental casting of titanium alloy, Part 2. Properties of titanium-nickel alloys, J Jap Res Soc Dent Mat Appl 37: 145-153, 1980. (in Japanese)

7) Takahashi, J., Okazaki, M., Kimura, H. and Furuta, Y.: Casting properties of Ni-Ti shape memory alloy, J Biomed MaterRes 18: 427-434, 1984.

8) Saburi, T., Tatsumi, T. and Nenno, S.: Effect of heat treatment on mechanical behavior of Ti-Ni alloys, J De Physique C4: 261-266, 1982.

9) Frank, R.P , Brudvik, J.S. and Nicholls, J.I.: A comparison of the flexibility of wrought wire and cast circumferential clasps, J Prosth Dent 49: 471-476, 1983. 


\title{
本号掲載論文の和文抄録
}

\author{
低銅型および高銅型アマルガムの硬さに及ぼす水銀/ \\ アロイ比の影響：修復物中心部と辺縁部との比較 \\ 中井宏之, 鈴木一臣, 橋本弘一*
}

岡山大学曾学部画科理工学講座

*城西歯科大学歯科材料学講座

高銅型アマルガムの硬さに及ぼす水銀/アロイ比の影 響を低銅型アマルガムと比較し，修復物中心と辺縁部の 硬さについてあ検討した。製造者指示比よりあ小さい比 で作製された修復物の硬さはアロイの種類を問わず小さ かった。一方，大きい比を用いた場合にも標準比よりあ 小さい硬さを示したが，低下の度合は単一組成型〉添加 材 (In, Pd) を含む単一組成型>配合型 (削片状, 球状 のいずれも) となり，単一組成型の一部が特に大きく低
下した。

高銅型アマルガム修復物の中心部の硬さは低銅型アマ ルガムに比べて著しく大きかったが，水銀/アロイ比を 変化させるととによって低下した。これは辺縁部におい て特に著しく, また低銅型アマルガムの場合よりあ著し かった。高銅型アマルガムは操作因子の影響が大きいの で，低銅型アマルガムよりあ入念な取扳いが必要である ことがわかった。

低銅型および高銅型アマルガム修復物の硬さ分布

中井宏之, 鈴木一臣, 橋木弘一*

岡山大学菌学部茵科理工学講座

粒状と銅含有量の異なる 4 種のアロイを用いて臨床的 な方法で入念に作製されたアマルガム修復物の切断面に ついて，硬さの分布を微小硬度計によって調べた。高銅 型アマルガムはいずれあ低銅型アマルガムに比べて著明 に大きい硬さを示したが，単一組成型高銅アマルガムは 特に大きい值を示した。窝洞側壁に接するアマルガムの 硬さは，中心部に比べて著明に低かったが，低銅型削片 状アマルガムが特に小さな值を示した。修復物の上,

\section{*城西歯科大学歯科材料学講座}

中，底層部についてみると，上首部の硬さが著明に小さ く, 特に単一組成型高銅了ロイにあきらかであった。以 上にのべたととから, アマルガム辺縁部の硬さはアロイ の種類にかかわらず中心部より著明に低いととがわかっ た。従って，高銅型アマルガムの辺縁部の機械的性質 は,一般的に用いられる機械的テストの結果から予想さ れるほど低銅型アマルガムよりも大きくはないととがわ かった。

\section{超弾性 Ni-Ti 合金の歯科鋳造}

\section{高橋純造*, 岡崎正之*, 木村博*, 古田安宏** \\ *大阪大学歯学部蒾科理工学講座 $* *$ 大阪歯科学院專門学校}

$\mathrm{Ni}-43.5 \mathrm{wt} \% \mathrm{Ti}$ 合金の丸棒を，種々の鋳造条件で準 備した。コージライト・ルツボで溶融し, リン酸塩系埋 没材鋳型に鋳造した試験片は，銅ルツボで溶融し、リン 酸塩系埋没材鋳型に鋳造したあのより, 強度, 伸びが小
さかった。すべての鋳造体は，室温で超弾性を示した。 回復最大ひずみは，約 $1.8 \%$ であった。本合金製の鋳造 クラスプは, 模型に良く適合し, 良いしなやかさと超弾 性をしめした。 